\title{
High-Throughput Screening of Natural Products for Cancer Therapy
}

Authors

Affiliations
Alan L. Harvey ${ }^{1}$, Ian A. Cree ${ }^{2}$

${ }^{1}$ Strathclyde Institute of Pharmacy and Biomedical Sciences, University of Strathclyde, Glasgow, U.K.

2 Translational Oncology Research Centre, Queen Alexandra Hospital, Portsmouth, U. K.

\section{Key words}

- cell-based assays

- protein kinases

- cytotoxicity

- natural products received January 30,2010

revised June 29,2010

accepted July 1,2010

Bibliography

DOI http://dx.doi.org/

10.1055/s-0030-1250162

Published online July 15, 2010

Planta Med 2010; 76:

1080-1086 @ Georg Thieme

Verlag KG Stuttgart · New York . ISSN 0032-0943

\section{Correspondence}

Alan L. Harvey

Strathclyde Institute

of Pharmacy and

Biomedical Sciences

University of Strathclyde

27 Taylor Street

Glasgow G4 ONR

United Kingdom

Phone: +441415534155

Fax: +441415528376

a.l.harvey@strath.ac.uk

\section{Abstract \\ $\nabla$}

Natural products have been the biggest single source of anticancer drugs and there are continued efforts to explore the chemical diversity provided by nature in order to find new lead compounds. Bioassay test methods have developed into high throughput screening assays using both cell-based and molecular approaches. The various

\section{Introduction}

$\nabla$

Natural products have been a long and continuing source of anticancer compounds [1-3]. Some of the most valuable compounds (such as paclitaxel and the Vinca alkaloids) were discovered serendipitously or from slow and laborious in vivo screening. In the last 20 years, there have been great developments in methods for both cellbased and biochemical assays so that compounds can be tested rapidly for bioactivity. Commonly available equipment allows such assays to be conducted in multiwell plates, from 96-well to much higher densities such as 1536-well and even denser formats. This approach is commonly referred to as high-throughput screening (HTS), even if the level of throughput to qualify as "high" varies from user to user. With the widespread availability of HTS facilities in industry [4] and in academia $[5,6]$, there should be enhanced possibilities for discovering new active natural products that can form the basis for new drugs against cancer. This review will outline some of the available screening systems, highlighting those that have been used to screen collections of natural products. The screens can be used both for the detection of initial "hits" (i.e., compounds with activity against the primary target, even if potency is rather low, e.g., $\mathrm{IC}_{50}$ in the $5-10 \mu \mathrm{M}$ range) and for selection of "leads" (i.e., compounds with higher activity than hits, typically $1 \mu \mathrm{M}$ or less, ways to detect effects on cell viability and cell proliferation are summarised and examples are given of developments using three-dimensional cultures and cancer stem cells. Cell-based reporter assays have also been created in order to look more directly for effects on specific physiological pathways. The molecular assays include those directed at microtubules and related proteins and at many different protein kinases. and with some degree of known selectivity for the therapeutic target).

Various sources of natural products have been and are continuing to be used: plants, including those from traditional Chinese medicine $[7,8]$, marine micro- and macroorganisms [9-12], microbial broths [13], and modified natural products [14-15]. Although there seems to be a perception that natural products (especially when used as extracts rather than single compounds) cause frequent artefacts with many assay systems, personal experience indicates that the number of false positives in a wide range of assays is no greater with natural products than with commercial screening collections of supposedly drug-like compounds (A.L. Harvey, unpublished). Where possible, screening campaigns should involve use of two different types of experimental read-out (e.g., one based on fluorescence, another based on chemiluminescence, etc.) so that compounds or extracts that interfere with one detection system can be picked out because they are unlikely to appear as active in the other detection system.

\section{Cell-Based Assays \\ $\nabla$}

\section{Cell growth/cell death}

Since cancer cells are characterised, in part [16], by their ability to proliferate, an obvious approach to HTS for anticancer activity is to look for com- 
pounds that reduce growth of cancer cells in culture. Many cell lines are available that have been derived from a wide variety of human cancers, and effects of compounds on such cells can be compared to effects on non-cancerous cells to establish if there is any possible selectivity for tumour-derived cells. A recent example of the successful use of cell-based screens was with a panel of prostate cancer cells and non-cancerous prostate epithelial cell lines [17], and the marine-derived compound batzelline was shown to be selectively cytotoxic to pancreatic cells lines over the normal kidney epithelial cell line Vero [18].

There are many methods for quantifying cell growth or cell death in culture [19]: these include incorporation of radiolabelled thymidine, exclusion of trypan blue, measurement of metabolic activity, changes in ATP levels, release of intracellular enzymes, and binding of DNA-staining dyes (@ Table 1 ). They generally can be adapted to run on 384-well plates or even on 1536-well plates [20]. There are also methods to detect increases in apoptosis (e.g., $[21,22])$. However, there is no ideal detection method because test compounds can cause interference with the measurement system: for example, quenching or enhancing scintillation counts with radiolabels, interference with visible light or fluorescent signals, or inhibition of reagents (such as luciferase) in the assays (see, e.g., [23-25]). It goes without saying that all initial hits should be treated with scepticism until they have been confirmed by more extensive testing. Running different assays (e.g., one for cell viability and one for cell death) in parallel can be beneficial [26], particularly if the assays use different detection technologies (e.g., a UV-absorbance change and a chemiluminescent signal). Such assays can be run on the same wells [27, 28 ], and also be multiplexed with a cell-based assay to detect the apoptotic marker, caspase-3 [29].

Since cells in culture are in an artificial environment [30] and are generally growing much faster than they would in situ, there are concerns about the correlation of results from simple cell growth studies with those from in vivo experiments, and about their ability to predict activity of drugs in patients. Some attempts have been made to address this problem by making the culture environment less compatible with cell proliferation to make it more akin to the cellular environment in vivo, e.g., by using depleted medium and culture plates that discourage attachment and proliferation of cells [31].

Other confounding artefacts can include competition between compounds which bind to DNA and cell death markers (such as Sytox Green) that fluoresce when they bind to DNA. Metabolic in- dicators such as MTT and Alamar Blue can give misleading results depending on the time when the cells are sampled: damaged cells can be on the way to dying but their metabolism may be temporarily enhanced, leading to an overestimate of live cells (unpublished observations; [32]). Conversely, the MTT assay can underestimate cell numbers in conditions of high cell density, possibly because this reduces metabolic activity [33]. Nonspecific reduction of MTT to formazan can be produced by chemicals such as ascorbate and sulphydryl compounds present in culture media [34].

While assays with cell lines for cell death and proliferation are convenient for screening, there are concerns that compounds which kill readily proliferating cancer cells may not eliminate the tumour because of the persistence of cancer stem cells. Such cells are resistant to many anticancer drugs, and drug treatment may even induce their appearance [35]. There is, therefore, considerable interest in finding agents that are effective against cancer stem cells $[36,37]$. A problem is that such cells are normally found in very low abundance so that it is difficult to establish suitable HTS assays. One solution for breast cancer stem cells was recently demonstrated [35]. Mammary epithelial cell lines (normal and neoplastic) were enriched with cells with stem cell properties by being encouraged to undergo an epithelial to mesenchymal transition (the expression of E-cadherin was blocked by a short hairpin RNA). The resulting cells were resistant to doxorubicin and paclitaxel, and were suitable for HTS in a cell proliferation assay in 384-well plates. A screen of 16000 compounds revealed some that had some selectivity for the stem cell-like cells over normal cells (see results at http:// chembank.broad.harvard.edu). Salinomycin, an antibiotic originally from Streptomyces albus, was the most active of the compounds studied in detail. Salinomycin has recently been reported to be a potent inducer of apoptosis in a wide range of cancer cells [38].

Stem cells also have an enhanced ability to form colonies when plated at low densities and to grow as spheroids (see next section). Clonogenic assays tend to be suitable only for low-throughput screening, but a soft-agar method for HTS of compounds against cells' colony forming abilities has been published recently [39]. The method relies on an automated pipetting instrument, and it has been validated with three human colon cancer cell lines: the clinically used anti-metabolite 5-fluorouracil caused concentration-dependent reductions in colony formation (as measured using Alamar Blue to estimate living cell numbers).

Table 1 Cell-based assays in use for screening for anticancer activities.

\begin{tabular}{|c|c|c|c|c|}
\hline Target & $\begin{array}{l}\text { Formats } \\
\text { in use }\end{array}$ & Read-out & Comments & References \\
\hline $\begin{array}{l}\text { Cell proliferation and/or cell death } \\
\text { (cancer-derived cell lines and primary } \\
\text { tumour cells) }\end{array}$ & $\begin{array}{l}\text { 96-well, } \\
\text { 384-well, } \\
\text { 1536-well }\end{array}$ & $\begin{array}{l}{ }^{3} \mathrm{H} \text {-thymidine uptake, trypan blue } \\
\text { exclusion, ATP levels, metabolic activity } \\
\text { indicators, DNA exposure, etc. }\end{array}$ & $\begin{array}{l}\text { potential for interference of test } \\
\text { substances with read-out; } \\
\text { multiplexing recommended }\end{array}$ & {$[17-20,51]$} \\
\hline Apoptosis & as above & ELISA (cytokeratin [18]); fluorescence & as above & {$[21,22,29]$} \\
\hline Cancer stem cells & 384-well & standard cell growth assays & E-cadherin overexpression & [35] \\
\hline Colony-forming ability & 96-well & $\begin{array}{l}\text { relative fluorescence between two cell } \\
\text { layers }\end{array}$ & $\begin{array}{l}\text { may detect relevant phenotypic } \\
\text { behaviour of cancer cells }\end{array}$ & [39] \\
\hline Spheroids & 96-well & $\begin{array}{l}\text { acid phosphatase assay; apoptosis-ELISA } \\
\text { assay }\end{array}$ & $\begin{array}{l}\text { may better mimic the in vivo } \\
\text { behaviour of cancer cells }\end{array}$ & {$[45-47]$} \\
\hline $\begin{array}{l}\text { Reporter genes linked to molecular } \\
\text { targets (e.g., Kruppel-like factor } 5 \text {, } \\
\text { EGFR, ubiquitin-proteosome) }\end{array}$ & $\begin{array}{l}\text { 96-well, } \\
\text { 384-well }\end{array}$ & luciferase luminscence & $\begin{array}{l}\text { can reveal effects on selected } \\
\text { pathways so long as controls for } \\
\text { off-target effects are run }\end{array}$ & $\begin{array}{l}{[53,54,56,} \\
59]\end{array}$ \\
\hline Zebrafish embryos & 96-well & visual & not often high throughput & [103] \\
\hline
\end{tabular}


Most patients with cancer are treated with combinations of drugs in attempts to maximise therapeutic effects. Some screening methods have been adapted to look for potentially synergistic effects of anticancer agents. Combinations of two or three clinically used agents have been tested in various human cancer cell lines (e.g., [40] and in primary cultures established from human tumours [41]. There are statistically valid methods to define combinations that are synergistic in effect rather than being simply additive or even antagonistic. These methods can be used to screen for novel synergistic agents acting with standard drugs (e.g., [42]). Tests for synergism have also been applied in looking for agents that can enhance the effectiveness of the TNF family of death ligands $[43,44]$. In one study, 50000 compounds were screened for their ability to kill cells from a prostate cancer cell line in combination with an anti-FAS antibody [43]: eight selective compounds were identified. In another study, 16480 synthetic and natural product compounds were tested for their ability to enhance the effectiveness of the death receptor ligand TRAIL (TNF- $\alpha$ related apoptosis-inducing ligand) on a renal cancer cell line [44]. Initially, compounds were tested at one concentration alone and in the presence of a concentration of TRAIL that did not itself affect the viability of the cells. Hits were examined across a broad concentration range in the presence of a standard concentration of TRAIL. Eighteen confirmed synergistic compounds were found, and 14 of these were natural products, showing the value of including natural products in the compounds that were screened. Some of the synergistic compounds were effective at nanomolar concentrations. They appeared to act through a variety of mechanisms: interference with DNA, activation of caspase 8 , modulation of mitochondrial membrane potential, or elsewhere in the apoptotic pathway.

\section{Three-dimensional cultures}

Monolayers of cells in culture are obviously two-dimensional whereas solid tumours are three-dimensional. Cancer cells are less sensitive to cytotoxic drugs when grown in three-dimensional aggregates, and therefore, it may be more realistic to test compounds against cells grown in some sort of three-dimensional system.

There are several methods available for growing cells in small multicellular spheroids, and there have been attempts to adapt these for HTS [45-47]. It is possible to measure drug-induced increases in apoptosis in cultured spheroids grown from several human cancer cell lines [48]. There do not appear to be any reports of spheroid cultures in HTS for testing natural product collections for potential anticancer activity.

Another approach to providing a more realistic environment for cells is to grow them on a three-dimensional matrix. A mesh of electrospun collagen microfibres was found to support colony formation by a prostate cancer bone metastatic cell line [49]. The cells in the colonies more closely resembled cells in patients in terms of their sensitivity to drugs. If it is possible to standardise the scaffolds so that large numbers of replicate cultures can be produced, then this approach could provide a more realistic drug screening platform than the conventional monolayer cultures.

Efforts are also being put into use of automated imaging techniques to track movement of cancer cells through matrices. This was demonstrated with A549 lung cancer cells grown in a collagen gel. It is suggested that such methods could be developed for drug screening [50].

\section{Primary cells}

Cell lines can show significant differences in their behaviour from tumour-derived cells in primary cell culture or xenografts. Therefore, it might be more appropriate to use primary cell cultures from biopsies obtained from patients. Then the difficulty becomes one of quantity and reliability of tissue access. Primary cultures from ovarian tumours can grow successfully in 384-well plates, thereby reducing the number of cells needed for each assay point (S. Glaysher and I.A. Cree, unpublished). This method allows HTS of compound collections for anticancer activity in primary cell cultures. In a pilot study [51], 5605 plant extracts were each screened against primary cultures established from three recurrent ovarian tumours. Sixty extracts were active, and 13 of these had previously been found to be positive in a breast cancer cell line screen (ZR75 cells) so that 47 were previously unknown from the cell line screen; work continues in order to characterise the active components in the extracts. This study shows that it is possible to use an HTS approach for large libraries of potential anticancer compounds against tumour-derived cells where previously the cell numbers required for such studies could not be achieved without use of cell lines.

In another example of the use of primary cells, B-cell chronic lymphocytic leukaemia cells were used to screen collections of compounds based on natural product scaffolds (spiroketals and fused bicyclic acetals). Potent apoptosis-inducing cytotoxic compounds were identified [52].

\section{Cell-based reporter assays}

Although simple growth and viability assays with cancer cell lines have the advantages of convenience, they do not immediately reveal insights into mechanisms of action of compounds. Mechanistic cell-based assays can, however, be created by engineering cells to express particular molecular targets ( Table 1). For example, a transcription factor, Kruppel-like factor 5, has been found to be important for the proliferation of intestinal epithelial and colorectal cancer cells, and a suitable cancer line was stably transfected with a luciferase reporter gene to allow convenient screening for compounds that affected the expression of Kruppel-like factor 5 [53]. Wortmannin was one of the hits detected in the preliminary screening experiment, and this, and other hits, were shown to reduce growth of colorectal cancer cell lines.

An assay for compounds affecting the epidermal growth factor receptor (EGFR) was created by transfecting the receptor into a cell line (32D) so that proliferation was stimulated by EGF. Nine compounds were found to be hits out of the 20000 screened [54]. In another recent example of the development of reporter assays for detection of compounds with anticancer potential, a luciferase-based system for detecting autophagy was described [55].

Many other targets are being used in the search for novel anticancer agents, and a few are included here as illustrations. One of the most established of these targets is the ubiquitin-proteosome pathway because one inhibitor, bortezomib, is in clinical use for multiple myeloma. A bioluminescence assay that is suitable for use with natural product extracts has been developed [56] and led to the identification of physalin B from the plant Physalis angulata as a novel inhibitor of proteosome function [57].

There has also been considerable interest in inhibitors of heat shock protein 90 (hsp90) [58], and assays are available, both cell-based [59] and molecular [60,61]. Several natural products, 
including geldanamycin and radicol, inhibit hsp90 [62]. The transcription factor hypoxia-inducible factor 1 (HIF-1) has attracted attention as a potential anticancer target. HTS assays are available (e.g., [63]), and natural products from several sources have provided some hit compounds $[64,65]$.

There has been considerable interest in the protein interactions of p53, a tumour-suppressor gene mutated in around $50 \%$ of human cancers regulated by interaction with hMDM2 in particular [66]. Several natural product screens have been conducted, and as well as standard cellular methods, molecular methods such as phage display [67] and electrochemiluminescence methods [68]. The electrochemiluminescence method was developed to overcome some of the problems of using extracts in protein interaction assays and was used to screen a library of more than 144000 natural product extracts [68]. One natural product, sempervirine, was found to inhibit MDM2 auto-ubiquitination, MDM2-mediated p53 degradation, and led to accumulation of p53 followed by apoptosis in cells with wild-type p53.

Hits detected in such reporter assays have to be validated by showing that they are not interfering with the reporter system itself. They also need to be tested directly against the presumed target to show that they are acting through the desired mechanism. For example, a screen of marine natural products using a cell line with a luciferase reporter linked to the Wnt pathway revealed compounds that indirectly affected that pathway through inhibition of histone deacetylase (HDAC) [69]. However, an advantage of cell-based reporter assays is that the active compounds must gain access to their site of action so that an element of bioavailability is already established.

\section{Molecular Assays}

\section{$\nabla$}

With the introduction of the so-called targeted anticancer drugs, there has been a renewal of confidence in the usefulness of assays based on molecular targets [70]. Time will tell whether such faith is justified.

Nevertheless, molecular assays do have advantages over cellbased assays: they are less laborious, they generally require less test material, they are faster, and they are more amenable to ultra-high-throughput screening (○ Table 2). However, hits from molecular assays still have to be shown to have the required selectivity for the target and to retain their activity in more integrated situations.

\section{Tubulin and microtubule targeted agents}

Given the success of taxanes (which stabilise microtubules) and Vinca alkaloids (which bind to tubulin and disrupt microtubules), it is not surprising that HTS methods have been developed for looking at actions on tubulin and microtubules, and on related proteins such as kinesins [71]. Novel inhibitors are being found from natural products (e.g., eleutherobin, epothilones and laulimalide [72-74]).

\section{Protein kinases}

Inhibitors of various receptor-associated tyrosine kinases have successfully reached the market as agents for specific types of cancers (e.g., [75-79]), and there are several inhibitors of cyclindependent kinases and inhibitors of Aurora A or polo-like kinases in clinical trials $[80,81]$. Since the individual kinase enzymes are available from commercial suppliers and since there are several commercially available methods for determining kinase activity $[76,82]$, it is feasible to undertake HTS against particular kinases that are believed to be of therapeutic relevance. Not all assay formats will be ideal for use with natural products. For example, an ELISA-based assay was shown to be sensitive to antioxidants in plant extracts, whereas a time-resolved fluorescence assay was more reliable [83].

When hits are found, their specificities can be determined against a broad panel of kinases via a "kinome-wide" profiling service offered by one of several firms (see, e.g., [84]).

Examples of successful screening campaigns are those on PIM1 kinase, a serine-threonine kinase that functions as an oncogene [85] and glycogen synthase $3 \beta$ (GSK3 $\beta$ ) [86]. An ELISA-based assay for PIM1 kinase was used to screen 1200 compounds related to known kinase inhibitors, and seven confirmed hits were found. Six of these were flavonoids with $\mathrm{IC}_{50}$ values of 1 to $60 \mu \mathrm{M}$. Testing additional flavonoids led to the identification of quercetagetin, which had an $\mathrm{IC}_{50}$ of $0.34 \mu \mathrm{M}$ and which was much less active against a range of other kinases. Quercetagetin was shown to inhibit the proliferation of prostate cancer cells in culture [85]. With GSK3 $\beta$, analogues of the natural product staurosporine led to the design and synthesis of benzofuran-3-yl(indol-3-yl)maleimides, some of which were found to have subnanomolar potency against the enzyme [86]. Several of the compounds were potent inhibitors of growth of pancreatic tumour cell lines in culture.

Most of the kinase inhibitors developed to date bind to the ATP binding site on the enzyme, leading to concerns about achieving

Table 2 Molecular assays in use for screening for anti-cancer activities.

\begin{tabular}{|c|c|c|c|c|}
\hline Target & $\begin{array}{l}\text { Formats } \\
\text { in use }\end{array}$ & Read-out & Comments & References \\
\hline Kinesins & 96-well & $\begin{array}{l}\text { ATPase activity - } \\
\text { colorimetric }\end{array}$ & $\begin{array}{l}\text { possible interference from coloured } \\
\text { natural products }\end{array}$ & {$[71]$} \\
\hline Kinases & 96-well & $\begin{array}{l}\text { ELISA; time-resolved } \\
\text { fluorescence }\end{array}$ & $\begin{array}{l}\text { TRF better with natural products than } \\
\text { ELISA }\end{array}$ & {$[83]$} \\
\hline PIM1 kinase & 96-well & ELISA & recombinant enzyme & {$[85]$} \\
\hline p38 $\alpha$ & 96-well & fluorescence & requires fluorescently tagged enzyme & {$[87]$} \\
\hline $\begin{array}{l}\text { Protein-protein interactions ( } \beta \text {-catenin/ } \\
\text { proteosome; polo-like kinase) }\end{array}$ & $\begin{array}{l}\text { 384-well, } \\
\text { 1536-well }\end{array}$ & fluorescence & $\begin{array}{l}\text { robust enough for natural product } \\
\text { screening }\end{array}$ & {$[89-91]$} \\
\hline Heparanase & 96-well & colorimetric & synthetic substrate & [99] \\
\hline$y$-Secretase & 1536-well & $\begin{array}{l}\text { time-resolved } \\
\text { fluorescence }\end{array}$ & $\begin{array}{l}\text { TRF may be less prone to artefacts } \\
\text { than other systems }\end{array}$ & [100] \\
\hline Leucine aminopeptidase & 96-well & fluorescence & $\begin{array}{l}\text { high sensitivity from choice of } \\
\text { substrate }\end{array}$ & {$[101]$} \\
\hline
\end{tabular}


requisite selectivity for the targeted enzyme. Allosteric inhibitors should, in theory, be more selective, although their discovery is more difficult with conventional assay methods. An approach to finding allosteric inhibitors has been to modify the enzyme with a fluorescent tag so that conformational changes can be detected. This has been successful with the serine/threonine kinase p38alpha and with the tyrosine kinase cSrc $[87,88]$.

Another approach to selectivity is to look for compounds that can disrupt the interactions between the kinase enzyme subunit and essential regulatory accessory proteins. Such protein-protein interactions are often regarded as "non-druggable", but this is not necessarily the case. For example, through a protein fragment complementation assay, Hashimoto et al. [89] screened over 120000 natural product samples against different protein-protein interactions of proteins relating to $\beta$-catenin and to proteasome assembly. Several hits with $\mathrm{IC}_{50}$ values between 1 and $20 \mu \mathrm{M}$ were found, and one hit from a fungal extract has an $\mathrm{IC}_{50}$ value of $20 \mathrm{nM}$ and its complete structure is being resolved. In terms of kinases, fluorescence polarisation assays have been described for the protein binding domains of the polo-like kinases $[90,91]$. From a screen of 22461 compounds, a natural product, thymoquinone, and a synthetic analogue termed poloxin were found to inhibit the protein binding domain of polo-like kinase 1 [92]. Poloxin was shown to cause mitotic arrest in HeLa cells. Similar assays for protein-protein interactions with Src kinases [93] found various plant-derived natural products to be active [94].

\section{Other enzymes}

In addition to the protein kinases, topoisomerases are well-established as targets for anticancer drugs [95,96], and HTS assays are available. Active compounds against topoisomerase 1 include the plant alkaloid camptothecin (which led to the clinically used drugs topotecan and irinotecan), and, for topoisomerase 2, etoposide (an analogue of podophyllotoxin from the mayapple Podophyllum peltatum) and doxorubicin (an anthracycline antibiotic related to daunomycin from Streptomyces peucetius).

Other enzymes being looked at as potential targets for new anticancer agents and for which HTS assays have been developed include: dual specificity phosphatases [97,98]; heparanase [99]; $\gamma$-secretase [100]; leucine aminopeptidases [101]; and histone deacetylases (HDACs) [102].

\section{Conclusions}

$\nabla$

Molecular and cell-based high-throughput assays will continue to be developed and used to screen natural products as well as synthetic compounds for potential anticancer activity. Although many assays are available and many collections of natural products are also available, it is safe to say that not all of the compounds have been tested on all of the assays: there is still potential for new leads to be generated. Another possibility is to go beyond cell-based assays in culture and use in vivo phenotypic screens. Zebrafish embryos can be used in 96-well plates and, therefore, have potential for relatively high-throughput screening [103]. Cancers can be induced by exposing zebrafish embryos to chemicals such as $N$-nitrosodiethylamine, or human cancer cells can be transplanted into zebrafish embryos. If the transplanted cells have been engineered to express, e.g., green fluorescent protein, the development of the tumour cells can be conveniently monitored. Zebrafish embryos can also be genetically engi- neered to express human oncogenes in order to produce cancerrelevant models, and some screening of natural products is taking place $[104,105]$.

\section{References}

1 Newman DJ, Cragg GM. Natural products as sources of new drugs over the last 25 years. J Nat Prod 2007; 70: 461-477

2 Butler MS. Natural products to drugs: natural product-derived compounds in clinical trials. Nat Prod Rep 2008; 25: 475-516

3 Harvey AL. Natural products in drug discovery. Drug Discov Today 2008; 13: 894-901

4 Mayr LM, Bojanic D. Novel trends in high-throughput screening. Curr Opin Pharmacol 2009; 9: 580-588

5 Hergenrother PJ. Obtaining and screening compound collections: a user's guide and a call to chemists. Curr Opin Chem Biol 2006; 10: 213-218

6 Frearson JA, Collie IT. HTS and hit finding in academia - from chemical genomics to drug discovery. Drug Discov Today 2009; 14: 1150-1158

7 Efferth T, Kahl S, Paulus K, Adams M, Rauh R, Boechzelt H, Hao X, Kaina B, Bauer $R$. Phytochemistry and pharmacogenomics of natural products derived from traditional Chinese medicine and Chinese materia medica with activity against tumor cells. Mol Cancer Ther 2008; 7: 152-161

$8 \mathrm{MaX}$, Wang Z. Anticancer drug discovery in the future: an evolutionary perspective. Drug Discov Today 2009; 14: 1136-1142

9 Fenical W, Jensen PR, Palladino MA, Lam KS, Lloyd GK, Potts BC. Discovery and development of the anticancer agent salinosporamide A (NPI0052). Bioorg Med Chem 2009; 17: 2175-2180

10 Glaser KB, Mayer AM. A renaissance in marine pharmacology: from preclinical curiosity to clinical reality. Biochem Pharmacol 2009; 78: $440-448$

11 Menna M. Antitumor potential of natural products from Mediterranean ascidians. Phytother Rev 2009; 8: 461-472

12 Molinski TF, Dalisay DS, Lievens SL, Saludes JP. Drug development from marine natural products. Nat Rev Drug Discov 2009; 8: 69-85

13 Bailly C. Ready for a comeback of natural products in oncology. Biochem Pharmacol 2009; 77: 1447-1457

14 Coseri $S$. Natural products and their analogues as efficient anticancer drugs. Mini Rev Med Chem 2009; 9: 560-571

15 Peddibhotla S. 3-Substituted-3-hydroxy-2-oxindole, an emerging new scaffold for drug discovery with potential anti-cancer and other biological activities. Curr Bioactive Compounds 2009; 5: 20-38

16 Hanahan D, Weinberg RA. The hallmarks of cancer. Cell 2000; 100: 57-70

17 Iljin K, Ketola K, Vainio P, Halonen P, Kohonen P, Fey V, Grafström RC, Perälä M, Kallioniemi $O$. High-throughput cell-based screening of 4910 known drugs and drug-like small molecules identifies disulfiram as an inhibitor of prostate cancer cell growth. Clin Cancer Res 2009; 15: 6070-6078

18 Guzmán EA, Johnson JD, Carrier MK, Meyer CI, Pitts TP, Gunasekera SP, Wright AE. Selective cytotoxic activity of the marine-derived batzelline compounds against pancreatic cancer cell lines. Anticancer Drugs 2009; 20: 149-155

19 Galluzzi L, Aaronson SA, Abrams J, Alnemri ES, Andrews DW, Baehrecke EH, Bazan NG, Blagosklonny MV, Blomgren K, Borner C, Bredesen DE, Brenner C, Castedo M, Cidlowski JA, Ciechanover A, Cohen GM, De Laurenzi V, De Maria $R$, Deshmukh M, Dynlacht BD, El-Deiry WS, Flavell RA, Fulda S, Garrido C, Golstein P, Gougeon ML, Green DR, Gronemeyer H, Hajnóczky G, Hardwick JM, Hengartner MO, Ichijo H, Jäättelä M, Kepp O, Kimchi A, Klionsky DJ, Knight RA, Kornbluth S, Kumar S, Levine B, Lipton SA, Lugli E, Madeo F, Malomi W, Marine JC, Martin SJ, Medema JP, Mehlen P, Melino G, Moll UM, Morselli E, Nagata S, Nicholson DW, Nicotera P, Nuñez G, Oren M, Penninger J, Pervaiz S, Peter ME, Piacentini M, Prehn JH, Puthalakath H, Rabinovich GA, Rizzuto R, Rodrigues CM, Rubinsztein DC, Rudel T, Scorrano L, Simon HU, Steller H, Tschopp J, Tsujimoto Y, Vandenabeele P, Vitale I, Vousden KH, Youle RJ, Yuan J, Zhivotovsky B, Kroemer G. Guidelines for the use and interpretation of assays for monitoring cell death in higher eukaryotes. Cell Death Differ 2009; 16 : 1093-1107

20 Shum D, Radu C, Kim E, Cajuste M, Shao Y, Seshan VE, Djaballah H. A high density assay format for the detection of novel cytotoxic agents in large chemical libraries. J Enzyme Inhib Med Chem 2008; 23: 931-945

21 Hägg M, Bivén K, Ueno T, Rydlander L, Björklund P, Wiman KG, Shoshan $M$, Linder $S$. A novel high-through-put assay for screening of pro-apoptotic drugs. Invest New Drugs 2002; 20: 253-259 
22 Antczak C, Takagi T, Ramirez CN, Radu C, Djaballah H. Live-cell imaging of caspase activation for high-content screening. J Biomol Screen 2009; 14: 956-969

23 Auld DS, Thorne N, Nguyen DT, Inglese J. A specific mechanism for nonspecific activation in reporter-gene assays. ACS Chem Biol 2008; 3 : 463-470

24 Auld DS, Southall NT, Jadhav A, Johnson RL, Diller DJ, Simeonov A, Austin $C P$, Inglese J. Characterization of chemical libraries for luciferase inhibitory activity. J Med Chem 2008; 51: 2372-2386

25 Shoichet BK. Screening in a spirit haunted world. Drug Discov Today 2006; 11: 607-615

26 Riss TL, Moravec RA. Use of multiple assay endpoints to investigate the effects of incubation time, dose of toxin, and plating density in cellbased cytotoxicity assays. Assay Drug Dev Technol 2004; 2: 51-62

27 Niles AL, Moravec RA, Eric Hesselberth P, Scurria MA, Daily WJ, Riss TL. A homogeneous assay to measure live and dead cells in the same sample by detecting different protease markers. Anal Biochem 2007; 366: 197-206

28 Niles AL, Moravec RA, Riss TL. Multiplex caspase activity and cytotoxicity assays. Methods Mol Biol 2008; 414: 151-162

29 Cen H, Mao F, Aronchik I, Fuentes RJ, Firestone GL. DEVD-NucView488: a novel class of enzyme substrates for real-time detection of caspase-3 activity in live cells. FASEB J 2008; 22: 2243-2252

30 Halliwell $B$. Oxidative stress in cell culture: an under-appreciated problem? FEBS Lett 2003; 540: 3-6

31 Fernando A, Glaysher S, Conroy M, Pekalski M, Smith J, Knight LA, Di Nicolantonio F, Cree IA. Effect of culture conditions on the chemosensitivity of ovarian cancer cell lines. Anticancer Drugs 2006; 17: 913-919

32 Sims JT, Plattner R. MTT assays cannot be utilized to study the effects of STI571/Gleevec on the viability of solid tumor cell lines. Cancer Chemother Pharmacol 2009; 64: 629-633

33 Liu WM, Dalgleish AG. MTT assays can underestimate cell numbers. Cancer Chemother Pharmacol 2009; 64: 861-862

34 Plumb JA, Milroy R, Kaye SB. Effects of the $\mathrm{pH}$ dependence of 3-(4,5-dimethylthiazol-2-yl)-2,5-diphenyl-tetrazolium bromide-formazan absorption on chemosensitivity determined by a novel tetrazoliumbased assay. Cancer Res 1989; 49: 4435-4440

35 Gupta PB, Onder TT, Jiang G, Tao K, Kuperwasser C, Weinberg RA, Lander $E S$. Identification of selective inhibitors of cancer stem cells by highthroughput screening. Cell 2009; 138: 645-659

36 Kawasaki BT, Hurt EM, Mistree T, Farrar WL. Targeting cancer stem cells with phytochemicals. Mol Interv 2008; 8: 174-184

37 Desbordes SC, Placantonakis DG, Ciro A, Socci ND, Lee G, Djaballah H, Studer $L$. High-throughput screening assay for the identification of compounds regulating self-renewal and differentiation in human embryonic stem cells. Cell Stem Cell 2008; 2: 602-612

38 Fuchs D, Heinold A, Opelz G, Daniel V, Naujokat C. Salinomycin induces apoptosis and overcomes apoptosis resistance in human cancer cells. Biochem Biophys Res Commun 2009; 390: 743-749

39 Thierbach $R$, Steinberg $P$. Automated soft agar assay for the highthroughput screening of anticancer compounds. Anal Biochem 2009; 387: $318-320$

40 Budman DR, Calabro A, Kreis W. Synergistic and antagonistic combinations of drugs in human prostate cancer cell lines in vitro. Anticancer Drugs 2002; 13: 1011-1016

41 Di Nicolantonio F, Neale MH, Knight LA, Lamont A, Skailes GE, Osborne RJ, Allerton R, Kurbacher CM, Cree IA. Use of an ATP-based chemosensitivity assay to design new combinations of high-concentration doxorubicin with other drugs for recurrent ovarian cancer. Anticancer Drugs 2002; 13: 625-630

42 Larsson DE, Hassan S, Larsson R, Oberg K, Granberg D. Combination analyses of anti-cancer drugs on human neuroendocrine tumor cell lines. Cancer Chemother Pharmacol 2009; 65: 5-12

43 Schimmer AD, Thomas MP, Hurren R, Gronda M, Pellecchia M, Pond GR, Konopleva M, Gurfinkel D, Mawji IA, Brown E, Reed JC. Identification of small molecules that sensitize resistant tumor cells to tumor necrosis factor-family death receptors. Cancer Res 2006; 66: 2367-2375

44 Booth NL, Sayers TJ, Brooks AD, Thomas CL, Jacobsen K, Goncharova EI, McMahon JB, Henrich CJ. A cell-based high-throughput screen to identify synergistic TRAIL sensitizers. Cancer Immunol Immunother 2009; 58: $1229-1244$

45 Kunz-Schughart LA, Freyer JP, Hofstaedter F, Ebner R. The use of 3-D cultures for high-throughput screening: the multicellular spheroid model. J Biomol Screen 2004; 9: 273-285
46 Ivascu A, Kubbies M. Rapid generation of single-tumor spheroids for high-throughput cell function and toxicity analysis. J Biomol Screen 2006; 11: 922-932

47 Friedrich J, Seidel C, Ebner R, Kunz-Schughart LA. Spheroid-based drug screen: considerations and practical approach. Nat Protoc 2009; 4: 309-324

48 Herrmann R, Fayad W, Schwarz S, Berndtsson M, Linder S. Screening for compounds that induce apoptosis of cancer cells grown as multicellular spheroids. J Biomol Screen 2008; 13: 1-8

49 Hartman O, Zhang C, Adams EL, Farach-Carson MC, Petrelli NJ, Chase BD, Rabolt JF. Microfabricated electrospun collagen membranes for 3-D cancer models and drug screening applications. Biomacromolecules 2009; 10: 2019-2032

50 Adanja I, Debeir O, Mégalizzi V, Kiss R, Warzée N, Decaestecker C. Automated tracking of unmarked cells migrating in three-dimensional matrices applied to anti-cancer drug screening. Exp Cell Res 2010; 316: 181-193

51 Glaysher S, Clements C, Harvey AL, Cree IA. High throughput screening of potential anti-cancer agents in primary cell culture using an ATP based luminescence assay. Proceedings AACR 101st Annual meeting. Washington, DC; 2010

52 Milroy LG, Zinzalla G, Loiseau F, Qian Z, Prencipe G, Pepper C, Fegan C, Ley $S V$. Natural-product-like spiroketals and fused bicyclic acetals as potential therapeutic agents for B-cell chronic lymphocytic leukaemia. Chem Med Chem 2008; 3: 1922-1935

53 Bialkowska $A B, D u Y, F u$ H, Yang VW. Identification of novel smallmolecule compounds that inhibit the proproliferative Kruppel-like factor 5 in colorectal cancer cells by high-throughput screening. Mol Cancer Ther 2009; 8: 563-570

54 Lin WH, Song JS, Chang TY, Chang CY, Fu YN, Yeh CL, Wu SH, Huang YW, Fang MY, Lien TW, Hsieh HP, Chao YS, Huang SF, Tsai SF, Wang LM, Hsu JT, Chen YR. A cell-based high-throughput screen for epidermal growth factor receptor pathway inhibitors. Anal Biochem 2008; 377: 89-94

55 Farkas T, Høyer-Hansen M, Jäättelä M. Identification of novel autophagy regulators by a luciferase-based assay for the kinetics of autophagic flux. Autophagy 2009; 5: 1018-1025

56 Ausseil F, Samson A, Aussagues Y, Vandenberghe I, Creancier L, Pouny I, Kruczynski A, Massiot G, Bailly C. High-throughput bioluminescence screening of ubiquitin-proteasome pathway inhibitors from chemical and natural sources. J Biomol Screen 2007; 12: 106-116

57 Vandenberghe I, Créancier L, Vispé S, Annereau JP, Barret JM, Pouny I, Samson A, Aussagues Y, Massiot G, Ausseil F, Bailly C, Kruczynski A. Physalin $B$, a novel inhibitor of the ubiquitin-proteasome pathway, triggers NOXA-associated apoptosis. Biochem Pharmacol 2008; 76: 453-462

58 Taldone T, Sun W, Chiosis G. Discovery and development of heat shock protein 90 inhibitors. Bioorg Med Chem 2009; 17: 2225-2235

59 Hardcastle A, Tomlin P, Norris C, Richards J, Cordwell M, Boxall K, Rowlands $M$, Jones K, Collins I, McDonald E, Workman P, Aherne W. A duplexed phenotypic screen for the simultaneous detection of inhibitors of the molecular chaperone heat shock protein 90 and modulators of cellular acetylation. Mol Cancer Ther 2007; 6: 1112-1122

60 Avila C, Hadden MK, Ma Z, Kornilayev BA, Ye QZ, Blagg BS. Highthroughput screening for Hsp90 ATPase inhibitors. Bioorg Med Chem Lett 2006: 16: 3005-3008

61 Galam L, Hadden MK, Ma Z, Ye QZ, Yun BG, Blagg BS, Matts RL. Highthroughput assay for the identification of Hsp90 inhibitors based on Hsp90-dependent refolding of firefly luciferase. Bioorg Med Chem 2007; 15: 1939-1946

62 Amolins MW, Blagg BS. Natural product inhibitors of Hsp90: potential leads for drug discovery. Mini Rev Med Chem 2009; 9: 140-152

63 Xia M, Huang R, Sun Y, Semenza GL, Aldred SF, Witt KL, Inglese J, Tice RR, Austin CP. Identification of chemical compounds that induce HIF-1alpha activity. Toxicol Sci 2009; 112: 153-163

64 Nagle DG, Zhou YD. Natural product-based inhibitors of hypoxia-inducible factor-1 (HIF-1). Curr Drug Targets 2006; 7: 355-369

65 Nagle DG, Zhou YD. Marine natural products as inhibitors of hypoxic signalling in tumors. Phytochem Res 2009; 8: 415-429

66 Vousden KH, Lane DP. p 53 in health and disease. Nat Rev Mol Cell Biol 2007; 8: 275-283

67 Ishi K, Sugawara F. A facile method to screen inhibitors of protein-protein interactions including MDM2-p 53 displayed on T7 phage. Biochem Pharmacol 2008; 75: 1743-1750 
68 Sasiela CA, Stewart DH, Kitagaki J, Safiran YJ, Yang Y, Weissman AM, Oberoi P, Davydov IV, Goncharova E, Beutler JA, McMahon JB, O'Keefe $B R$. Identification of inhibitors for MDM2 ubiquitin ligase activity from natural product extracts by a novel high-throughput electrochemiluminescent screen. J Biomol Screen 2008; 13: 229-237

69 McCulloch MW, Coombs GS, Banerjee N, Bugni TS, Cannon KM, Harper $M K$, Veltri CA, Virshup DM, Ireland CM. Psammaplin A as a general activator of cell-based signaling assays via HDAC inhibition and studies on some bromotyrosine derivatives. Bioorg Med Chem 2009; 17: 21892198

70 Goldstein DM, Gray NS, Zarrinkar PP. High-throughput kinase profiling as a platform for drug discovery. Nat Rev Drug Discov 2008; 7: 391-397

71 Kozielski F, DeBonis S, Skoufias DA. Screening for inhibitors of microtubule-associated motor proteins. Methods Mol Med 2007; 137: 189207

72 Altmann $\mathrm{KH}$, Gertsch J. Anticancer drugs from nature - natural products as a unique source of new microtubule-stabilizing agents. Nat Prod Rep 2007; 24: 327-357

73 Gallagher Jr BM. Microtubule-stabilizing natural products as promising cancer therapeutics. Curr Med Chem 2007; 14: 2959-2967

74 Klar U, Hoffmann J, Giurescu M. Sagopilone (ZK-EPO): from a natural product to a fully synthetic clinical development candidate. Expert Opin Investig Drugs 2008; 17: 1735-1748

75 Browne BC, O'Brien N, Duffy MJ, Crown J, O'Donovan N. HER-2 signaling and inhibition in breast cancer. Curr Cancer Drug Targets 2009; 9: 419438

76 Eglen RM, Reisine T. The current status of drug discovery against the human kinome. Assay Drug Dev Technol 2009; 7: 22-43

77 Hartmann JT, Haap M, Kopp HG, Lipp HP. Tyrosine kinase inhibitors - a review on pharmacology, metabolism and side effects. Curr Drug Metab 2009; 10: 470-481

78 Ivy SP, Wick JY, Kaufman BM. An overview of small-molecule inhibitors of VEGFR signaling. Nat Rev Clin Oncol 2009; 6: 569-579

79 Modjtahedi H, Essapen S. Epidermal growth factor receptor inhibitors in cancer treatment: advances, challenges and opportunities. Anticancer Drugs 2009; 20: 851-855

80 Gautschi O, Heighway J, Mack PC, Purnell PR, Lara Jr PN, Gandara DR. Aurora kinases as anticancer drug targets. Clin Cancer Res 2008; 14: 1639-1648

81 Lapenna S, Giordano A. Cell cycle kinases as therapeutic targets for cancer. Nat Rev Drug Discov 2009; 8: 547-566

$82 \mathrm{Ma} \mathrm{H}$, Deacon S, Horiuchi $\mathrm{K}$. The challenge of selecting protein kinase assays for lead discovery optimization. Expert Opin Drug Discov 2008; 3: 607-621

83 Dufau I, Lazzari A, Samson A, Pouny I, Ausseil F. Optimization of a homogeneous assay for kinase inhibitors in plant extracts. Assay Drug Dev Technol 2008; 6: 673-682

84 Karaman MW, Herrgard S, Treiber DK, Gallant P, Atteridge CE, Campbell BT, Chan KW, Ciceri P, Davis MI, Edeen PT, Faraoni R, Floyd M, Hunt JP, Lockhart DJ, Milanov ZV, Morrison MJ, Pallares G, Patel HK, Pritchard S, Wodicka LM, Zarrinkar PP. A quantitative analysis of kinase inhibitor selectivity. Nat Biotechnol 2008; 26: 127-132

85 Holder S, Zemskova M, Zhang C, Tabrizizad M, Bremer R, Neidigh JW, Lilly $M B$. Characterization of a potent and selective small-molecule inhibitor of the PIM1 kinase. Mol Cancer Ther 2007; 6: 163-172

86 Gaisina IN, Gallier F, Ougolkov AV, Kim KH, Kurome T, Guo S, Holzle D, Luchini DN, Blond SY, Billadeau DD, Kozikowski AP. From a natural product lead to the identification of potent and selective benzofuran-3-yl(indol-3-yl)maleimides as glycogen synthase kinase 3beta inhibitors that suppress proliferation and survival of pancreatic cancer cells. J Med Chem 2009; 52: 1853-1863
87 Simard JR, Klüter S, Grütter C, Getlik M, Rabiller M, Rode HB, Rauh D. A new screening assay for allosteric inhibitors of CSrc. Nat Chem Biol 2009; 5: 394-396

88 Simard JR, Getlik M, Grütter C, Pawar V, Wulfert S, Rabiller M, Rauh D. Development of a fluorescent-tagged kinase assay system for the detection and characterization of allosteric kinase inhibitors. J Am Chem Soc 2009; 131: 13286-13296

89 Hashimoto J, Watanabe T, Seki T, Karasawa S, Izumikawa M, Seki T, Iemura S, Natsume T, Nomura N, Goshima N, Miyawaki A, Takagi M, ShinYa K. Novel in vitro protein fragment complementation assay applicable to high-throughput screening in a 1536-well format. J Biomol Screen 2009; 14: 970-979

90 Reindl W, Strebhardt K, Berg T. A high-throughput assay based on fluorescence polarization for inhibitors of the polo-box domain of pololike kinase 1. Anal Biochem 2008; 383: 205-209

91 Reindl W, Gräber M, Strebhardt K, Berg T. Development of highthroughput assays based on fluorescence polarization for inhibitors of the polo-box domains of polo-like kinases 2 and 3. Anal Biochem 2009; 395: 189-194

92 Reindl W, Yuan J, Krämer A, Strebhardt K, Berg T. Inhibition of polo-like kinase 1 by blocking polo-box domain-dependent protein-protein interactions. Chem Biol 2008; 15: 459-466

93 Kim LC, Song L, Haura EB. Src kinases as therapeutic targets for cancer. Nat Rev Clin Oncol 2009; 6: 587-595

94 Sperl B, Seifert MH, Berg T. Natural product inhibitors of protein-protein interactions mediated by Src-family SH2 domains. Bioorg Med Chem Lett 2009; 19: 3305-3309

95 Pommier Y. DNA topoisomerase I inhibitors: chemistry, biology, and interfacial inhibition. Chem Rev 2009; 109: 2894-2902

96 Nitiss JL. Targeting DNA topoisomerase II in cancer chemotherapy. Nat Rev Cancer 2009; 9: 338-350

97 Bakan A, Lazo JS, Wipf P, Brummond KM, Bahar I. Toward a molecular understanding of the interaction of dual specificity phosphatases with substrates: insights from structure-based modeling and high throughput screening. Curr Med Chem 2008; 15: 2536-2544

98 Johnston PA, Foster CA, Tierno MB, Shun TY, Shinde SN, Paquette WD, Brummond KM, Wipf P, Lazo JS. Cdc25B dual-specificity phosphatase inhibitors identified in a high-throughput screen of the NIH compound library. Assay Drug Dev Technol 2009; 7: 250-265

99 Hammond E, Li CP, Ferro V. Development of a colorimetric assay for heparanase activity suitable for kinetic analysis and inhibitor screening. Anal Biochem 2010; 396: 112-116

100 Shelton CC, Tian Y, Shum D, Radu C, Djaballah H, Li YM. A miniaturized 1536-well format gamma-secretase assay. Assay Drug Dev Technol 2009; 7: 461-470

101 Huang H, Tanaka H, Hammock BD, Morisseau C. Novel and highly sensitive fluorescent assay for leucine aminopeptidases. Anal Biochem 2009; 391: 11-16

102 Hauser AT, Jung M, Jung M. Assays for histone deacetylases. Curr Top Med Chem 2009; 9: 227-234

103 Zon LI, Le X. Potential of zebrafish for anticancer screening. Expert Opin Drug Discov 2008; 3: 1451-1460

104 Crawford AD, Esguerra CV, de Witte PA. Fishing for drugs from nature: zebrafish as a technology platform for natural product discovery. Planta Med 2008; 74: 624-632

105 Maule J, Richardson J, Clements C, Harvey A, Patton E. A pilot screen for natural inhibitors of cancer-relevant signalling pathways. 5th Eur Zebrafish Genet Dev Meeting, Amsterdam; 2007 